\title{
Ectopic cervical thymoma: An extremely rare tumor
}

\author{
Yusuf KAHYA ${ }^{1}($ ID) \\ Murat ÖZKAN ${ }^{1}$ (ID) \\ Ayşe UĞURUM \\ YÜCEMEN ${ }^{1}$ (ID) \\ Süleyman Gökalp \\ GÜNEŞ ${ }^{1}$ (ID) \\ Seher YÜKSEL ${ }^{2}$ (ID) \\ Rifat Murat $\mathrm{AKAL}^{\mathbf{1}}$ (ID)
}

\author{
${ }^{1}$ Department of Thoracic Surgery, Ankara University Faculty of Medicine, \\ Ankara, Turkey \\ ${ }^{1}$ Ankara Üniversitesi Tıp Fakültesi, Göğüs Cerrahisi Anabilim Dalı, \\ Ankara, Türkiye \\ 2 Department of Pathology, Ankara University Faculty of Medicine, \\ Ankara, Turkey \\ ${ }^{2}$ Ankara Üniversitesi Tıp Fakültesi, Patoloji Anabilim Dalı, Ankara, Türkiye
}

Cite this article as: Kahya Y, Özkan $M$, Uğurum Yücemen A, Güneş SG, Yüksel S, Akal RM. Ectopic cervical thymoma: An extremely rare tumor. Tuberk Toraks 2021;69(2):293-295

\section{Yazışma Adresi (Address for Correspondence)}

\section{Dr. Yusuf KAHYA}

Ankara Üniversitesi Tıp Fakültesi,

Göğüs Cerrahisi Anabilim Dalı,

ANKARA - TÜRKIYE

e-mail: dr.yusufkahya@hotmail.com

CCopyright 2021 by Tuberculosis and Thorax.

Available on-line at www.tuberktoraks.org.com
To the Editor

A 54-year-old female patient presented with a enlarging mass in the anterior part of the neck for 2 months. On physical examination, $3 \mathrm{~cm}$ in diameter, elastic, mobile tumor was palpable in her anterior part of the neck. Computed tomography (CT) scan of the neck and thorax revealed a soft tissue of $32 \times 28 \mathrm{~mm}$ in sizes with regular contours located in anterior cervical region (Figure 1A, B). Positron Emission Tomography showed lineer 18F-FDG accumulation with a SUVmax value of 4,2. An encapsulated, roundish tumor which was not associated with thyroid gland was totally excised through an anterior cervical incision (Figure 2A, B). Histopathologic examination was reported as thymoma (Type B1, stage Ila; according to the WHO classification and $8^{\text {th }}$ edition of the TNM staging system, respectively) showing immunoreactivity for HMWCK/LMWCK, CD3 and TdT. (Figure 3A-C, respectively). Since the lack of safety surgical margins microscopically, extended thymectomy through median sternotomy was performed in another session and pathologic examination was reported as tumor free thymus. Patient is asymptomatic and has no tumor recurrence on the postoperative $52^{\text {th }}$ month. 


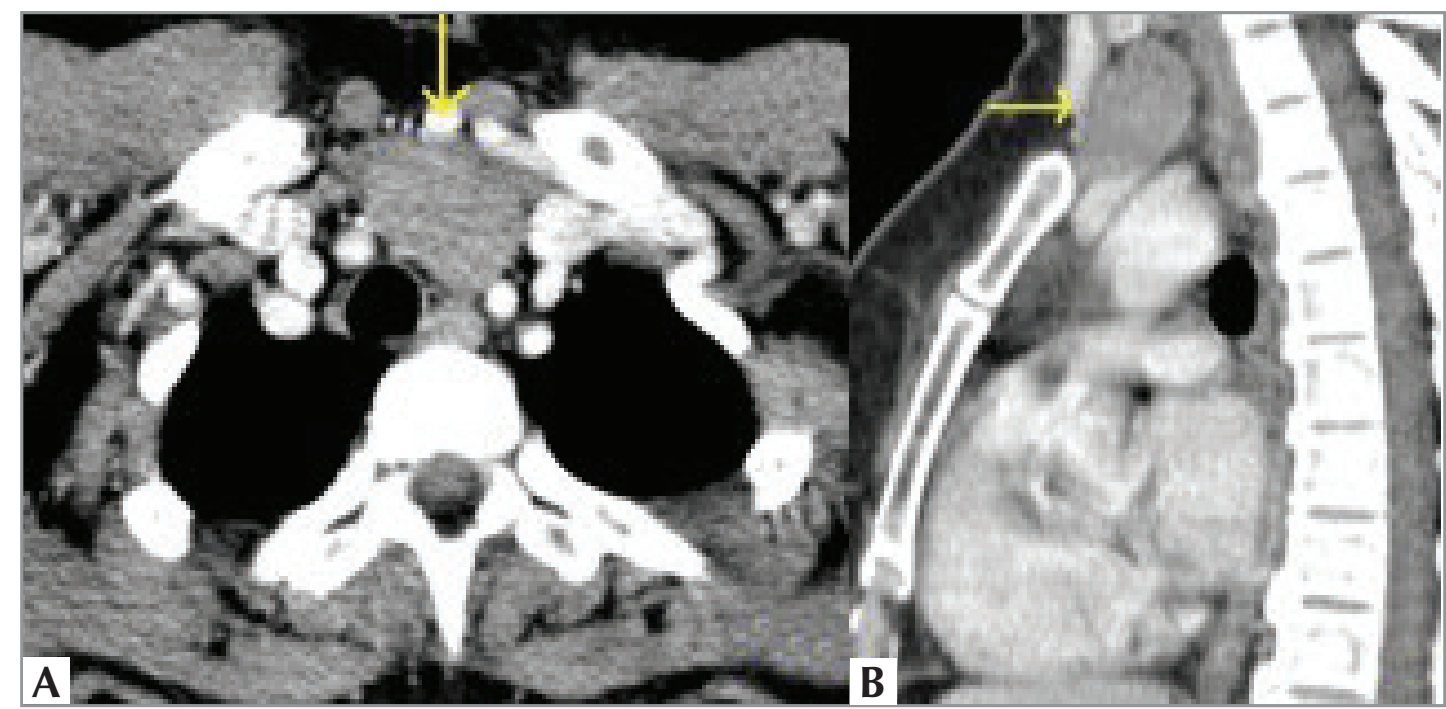

Figure 1. Axial A. and sagittal B. CT scans of neck and thorax (mediastinal window) shows soft tissue of $32 \times 28 \mathrm{~mm}$ in sizes with regular contours located in anterior cervical region.

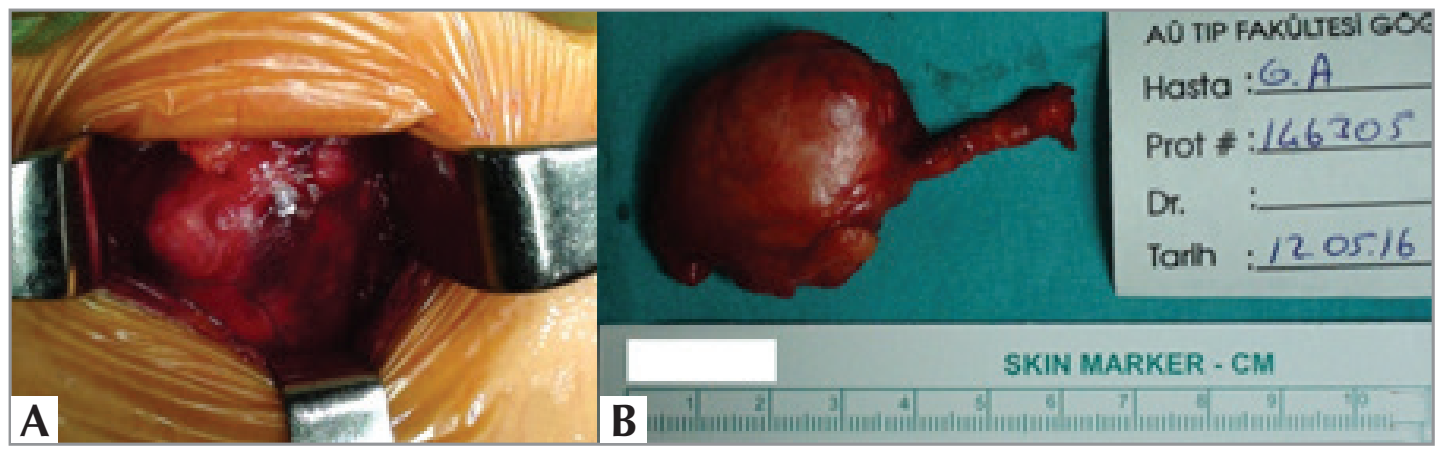

Figure 2. Exposure of the lesion with anterior cervical incision A., The specimen $\mathbf{B}$.

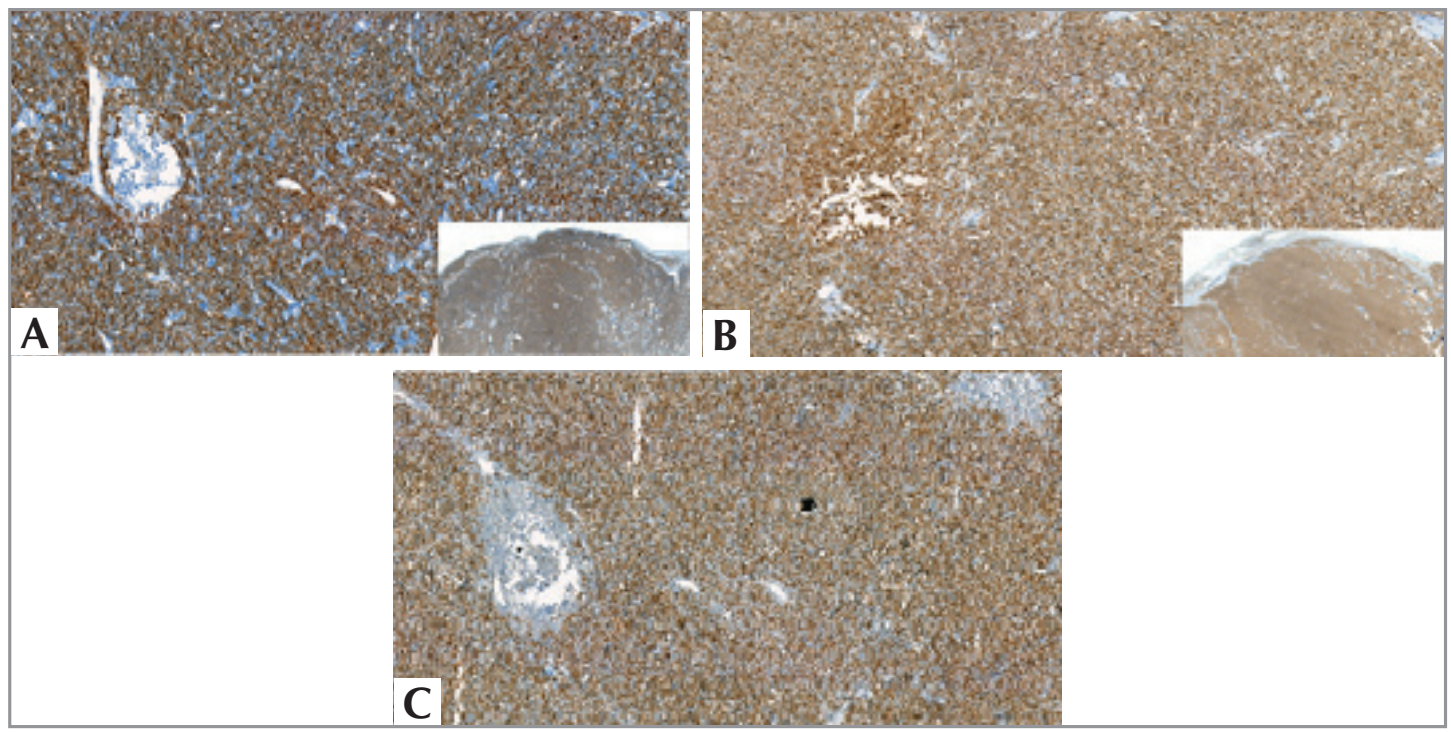

Figure 3. Histopathological examination of the tumor. Immunopositivity of the tumor cells for HMWCK/LMWCK A. CD3 B. and $\mathrm{TdT}(\mathrm{C})(\mathrm{x} 10$, inset $\mathrm{x} 2)$ 
Ectopic cervical thymoma (ECT) is an extremely a rare tumor that probably arises from ectopic thymic tissue trapped during migration of thymic primordia at the embryonic stage. They have been reported in a variety of sites such as neck, chest wall, pleura, lung and heart. Although thymoma arises from mediastinum commonly, they should be considered in the differential diagnosis of cervical masses. Complete surgical resection, when feasible, is the most successful modality of therapy for ECT.

\section{REFERENCES}

1. Weissferdt A, Moran CA. The spectrum of ectopic thymomas. Virchows Arch 2016; 469: 245-54.

2. Yokoyama S, Hayashida R, Yoshiyama K, Ozaki K, Matsuo $T$, Takamori S, et al. Ectopic cervical thymoma excised through a transcervical approach combined with video-assisted thoracoscopic surgery: a case report. Ann Thorac Cardiovasc Surg 2015; 21: 293-7. 